\title{
Effect of Intermittent Operation on the Productivity of a Single Basin Single Slope Passive Solar Still Containing Nanofluids
}

\author{
Ahmed Alm ElDin Mohamad ${ }^{1}$, ElShenawy A.E. ${ }^{2}$, Mohmad ElSamadony ${ }^{2}$ \\ ${ }^{1}$ Department of Basic Sciences, Tanta Higher Institute of Science and Technology, Egypt \\ ${ }^{2}$ Mechanical Power Engineering Departments, Faculty of Engineering, Tanta University, Tanta, Egypt. \\ *Corresponding author email: aalmeldin80@gmail.com
}

\begin{abstract}
This study assesses the effect of using two nanofluids; composed of Ferric Oxide $\left(\mathrm{Fe}_{2} \mathrm{O}_{3}\right)$ which is a metalic oxide and Red Clay Brick Waste (RCBW) containing over $60 \%$ $\mathrm{SiO}_{2}$ a nonmetalic oxide nanoparticles in ordinary water upon the performance of a basin solar still. An increase in the still productivity was observed for both the tested nanomaterials while the gain achieved with $\mathrm{Fe}_{2} \mathrm{O}_{3}$ exceeded that for $\mathrm{RCBW}$ at all the concentrations used. For both materials, the rise in concentration adds to the still yield which reached its maximum values; $11 \%$ and $9.5 \%$ for $\mathrm{Fe}_{2} \mathrm{O}_{3}$ and $\mathrm{RCBW}$ respectively at 0.01 vol \% then a depletion in the still yield was recorded with additional increase in concentration. The operation of the tested solar still is intermittent as the basin fluid is kept stationary during offshine sun hours. This leads to a continuous decrease in the still productivity over its operating period due to the loose of nanofluid stability causing aggregation, clustering and gravity aided sedimentation of the nanoparticles. These effects negatively affect the optical and heat transfer characteristics of the nanofluid suspension which determines the rate of vaporization and condensation of water in the still. Over $70 \%$ depletion in the still yield relative to that obtained in the first day of operation was recorded in the third day of operation for $\mathrm{Fe}_{2} \mathrm{O}_{3}$ nanofluids while four consecutive days of operation were needed for RCBW nanofluids to cause the similar effect. The negative effects of intermittent operation of the solar still containing nanofluids were more pronounced at higher nanoparticles concentrations. Current experimental research reveals that, ferric Oxide $\left(\mathrm{Fe}_{2} \mathrm{O}_{3}\right)$ and Red Clay Brick Waste (RCBW) containing over $60 \% \quad \mathrm{SiO}_{2}$ a nonmetalic oxide nanoparticles in ordinary water upon the performance of a basin solar still can improve the water distillation rate up to $25 \%-30 \%$ compared to the same ordinary distillation conditions.
\end{abstract}

Keywords: Nano fluids; solar still; productivity; water desalination.

\section{INTRODUCTION}

Water is the most abundant natural resource which covers three quarters of the earth's surface. However, only about 3\% of all water sources are potable; while less than $1 \%$ of this water is within human reach (rivers, lakes and ground water) and the remainder is permanent; snow cover, ice and permafrost. Due to these facts about $25 \%$ of the world countries does not have access to satisfy quality and quantity of fresh water and more than 80 countries most of them are developing and under developing countries face severe water shortage problems. Unfortunately, in addition to being scarce, freshwater is also very unevenly distributed. The United Nations has compared water consumption with its availability and has predicted that by the middle of this century 7 billion people will be faced with water scarcity [1, $2]$.

The problem of fresh water shortage can be partly solved by desalination of brackish and saline waters. Solar desalination is a technique used to obtain fresh water from saline or brackish water through utilizing solar energy. The device used to do this task is named solar still. In this device the radiant energy of the incident solar irradiation is absorbed and transferred as heat energy to the raw water present in the still basin. Such heat leads to vaporization of some of pure water which on condensation produces fresh water [3-5].

Solar stills are suitable for domestic applications, particularly in rural and remote areas, small islands, and big ships with no access to the electric grid. Solar stills are environmentally friendly, economically and technically more competitive than conventional gas or diesel engine powered reverse osmosis alternatives. The status of different types of solar stills and the allied researches in this field had been reviewed and a helpful summary containing the required information about different types of solar stills, their design methods and modeling is present in the literature $[6,7]$.

Solar stills have not widely applied because of their relatively low productivity. The various factors affecting the yield of solar stills are either climate conditions, which are mainly include: solar intensity, wind velocity and ambient air temperature, or design and operating conditions of the solar still. These include the shape and size of the still, the temperature difference between the water in the still and the glass cover, free surface area of water, inlet water temperature, glass cover type, thickness and inclination angle, the insulation type and thickness, depth of raw water present in the still basin and the presence of suspended solid particles in the raw water. The metrological parameters are out of control while the remaining parameters can be varied to enhance the productivity of solar stills $[8,9]$.

The productivity of the solar still is determined by the amount of the water vaporized from the still. The rate of water vaporization depends mainly upon the amount of solar thermal energy absorbed by the fluid present in the still basin and the heat transfer characteristics of that fluid. The absorption property of transparent liquids like water, was found to increase for visible wavelengths when solid particles are dispersed in such liquids. Optical properties of such suspensions depend on the solid particles material, size, 
shape and concentration [10]. Experiments revealed that suspensions of micro- sized solid particles in liquids improve heat transfer characteristics of the base fluid; mainly thermal conductivity and heat transfer coefficient and the recorded improvement increased with decreasing grain size of the used solid particles. This technology suffers from rapid gravity driven sedimentation of solid particles, high pressure drop, erosion, and clogging of the various system components [1012].

As the technology of nanosized particles rapidly developed, suspensions of nano - sized particles $(100>\mathrm{nm})$ in fluids, named nanofluids have been produced. The nanosized solid particles have larger relative surface areas per unit mass, less particle momentum, high mobility and better suspension stability than micron - sized particles [13].

Based on their applications nano particles have been made of various solid materials such as metals, metallic and nonmetallic oxides, carbon nano tubes and composite materials. The results of numerous studies reported that very small amounts of nano particles when suspended in base transparent fluids like water can lead to dramatic increase in the effective thermal conductivity and heat transfer coefficient relative to the base fluid In addition to enhancing solar radiation absorption in the visible and near infrared wavelength ranges in which most solar radiation energy is included [14, 15]. In general, experimental results of using nanofluids based on water as the base fluid in solar stills leads to a pronounced increase in the yield of these stills [16$18]$.

The present work deals with studying experimentally the effects of using pure Ferric Oxide $\left(\mathrm{Fe}_{2} \mathrm{O}_{3}\right)$ which is a metallic oxide and Red Clay Brick Waste (RCBW) containing over $60 \% \mathrm{SiO}_{2}$ a nonmetallic oxide nanoparticles in ordinary water in a basin solar still upon its productivity. This work is also concerned with studying the effect of operating the solar still for several consecutive days upon its yield as the still basin fluid is kept stationary during all the offshine sun hours. This leads to continuous changes in the concentration and homogeneity of the nanofluid suspension accompanied with changes in the optical and heat transfer characteristics of the suspension which determine the rate of water evaporation from the still basin and hence its productivity. Till now no treaty is signed in the literature to address this problem.

\section{EXPERIMENTAL METHODOLOGY DESCRIPTION}

\subsection{Experimental Setup}

A photograph of the whole experimental setup used in the current study is shown in (Figure 1 and Figure 2). This test rig consisted mainly of a conventional single basin single slope solar still. An inlet tube was provided to supply the still basin with ordinary water from a supply tank and a float was provided to ensure a constant depth of the fluid in the still basin. The still was provided with the necessary provisions needed for the connections of a circulating pump used for continuous circulation of the basin fluid on need. Drain tubes with the required valves were provided to empty the still on need. Sets of K-type thermocouples were used to measure temperatures of basin fluid, the inner surface of the glass cover and ambient a graduated cylinder is used to measure the quantity of the distillate produced. The direct photo of the test arrangement is presented in figure 1 and figure 2.

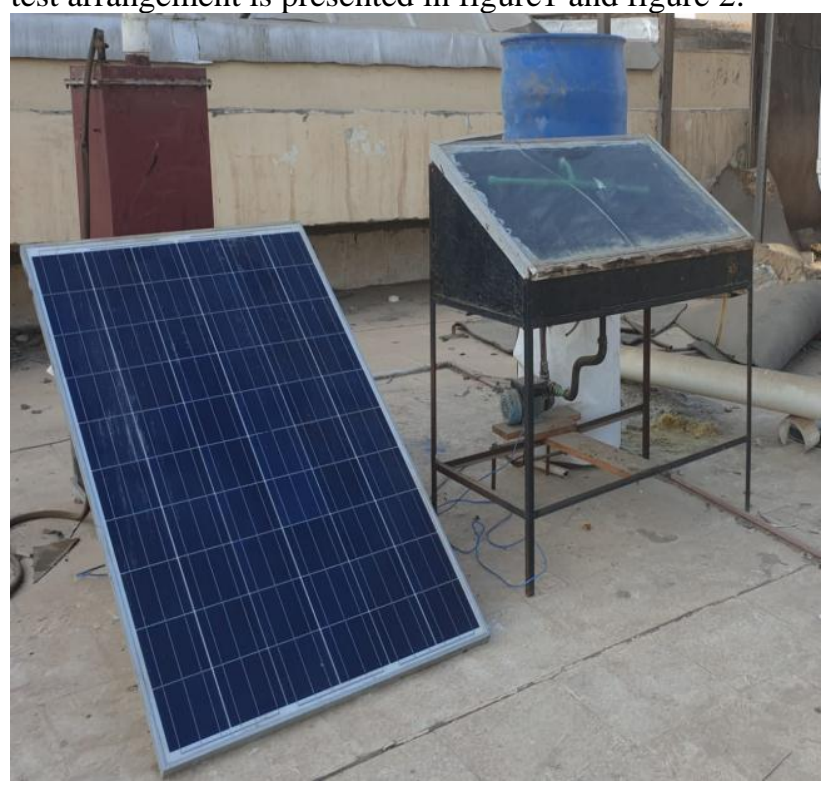

Fig. 1: The direct phot for the used experimental setup

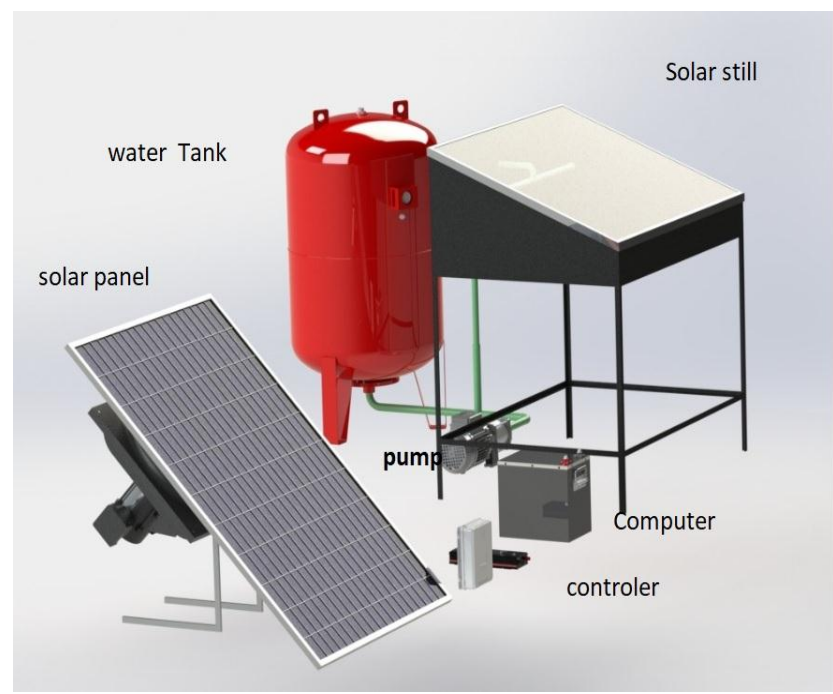

Fig. 2: Schematic diagram for the experimental setup

The still was fabricated using a double wall wooden box, the height of its lower vertical side equals $0.2 \mathrm{~m}$ while the height of the other vertical side was $0.62 \mathrm{~m}$. The absorber area of the basin was $0.7 \mathrm{~m}^{2}(1 \mathrm{~m} \mathrm{x} 0.7 \mathrm{~m})$ and galvanized steel plate $(0.002 \mathrm{~m}$ thick) covered the still base which was painted black. The inner wooden sides of the still were also painted black and a $0.1 \mathrm{~m}$ thick glass wool insulation is provided underneath the still basin and behind all the wooden vertical sides of the still. An ordinary clear glass of $0.04 \mathrm{~m}$ thick was used as the top cover of the solar still and was inclined at an angle of $30^{\circ}$ to the horizontal. The vaporized water condensed on the inner cold surface of the glass cover was collected in a galvanized steel trough fitted on the lower side of the glass cover and a plastic drain tube was used to discharge the condensate to a graduated cylinder outside the still. The whole solar still was made air and water vapor tight using a silicon based sealant between the glass cover and the 
sides of the still and between the various sides of the still walls.

\subsection{Nano materials preparation}

The salinity of the available ordinary water was $251 \mathrm{ppm}$ and it was used as the base fluid in preparing the nanofluids used in all experiments. The nano-sized solid materials used were Ferric Oxide $\left(\mathrm{Fe}_{2} \mathrm{O}_{3}\right)$ purchased from the local market and Red Clay Brick Waste (RCBW) which is a solid solution of silicon dioxide $\left(\mathrm{SiO}_{2}\right)$, aluminium oxide $\left(\mathrm{Al}_{2} \mathrm{O}_{3}\right)$, ferric oxide $\left(\mathrm{Fe}_{2} \mathrm{O}_{3}\right)$ in addition to some traces of other oxides. RCBW was selected from a pile of debris present in a red clay brick factory near Ibiar Gharbia Governorate, Egypt. This waste is generated during the production process because some of the produced bricks are broken during firing and transportation.

The characteristics of Ferric Oxide $\left(\mathrm{Fe}_{2} \mathrm{O}_{3}\right)$ used is given in Table 1, while the chemical composition of RCBW determined by $\mathrm{x}$-ray fluorescence (XRF) is given in Table 2. The average particle size for RCBW determined by laser granulometry was $92 \mathrm{~nm}$.

TABLE 1. Characteristics of $\mathrm{Fe}_{2} \mathrm{O}_{3}$ nanoparticles

\begin{tabular}{|c|c|c|c|}
\hline Type & $\begin{array}{c}\text { Equivalent diameter } \\
(\mathrm{nm})\end{array}$ & $\begin{array}{c}\text { Specific surface } \\
\text { area }(\mathrm{m} 2 / \mathrm{g})\end{array}$ & $\begin{array}{c}\text { Purity } \\
\%\end{array}$ \\
\hline $\mathrm{Fe}_{2} \mathrm{O}_{3}$ & 72 & 32 & 96 \\
\hline
\end{tabular}

TABLE 2: Chemical composition of RCBW

\begin{tabular}{|l|l|l|l|l|l|l|l|l|l|}
\hline Oxide & $\mathrm{SiO} 2$ & $\mathrm{Al203}$ & $\mathrm{Fe}_{2} \mathrm{O}_{3}$ & $\mathrm{CaO}$ & $\mathrm{MgO}$ & $\mathrm{Na} 2 \mathrm{O}$ & $\mathrm{K} 2 \mathrm{O}$ & $\mathrm{TiO2}$ & others \\
\hline $\begin{array}{l}\% \\
\text { (mass) }\end{array}$ & $\mathbf{6 5 . 9 2}$ & $\mathbf{2 0 . 0 8}$ & $\mathbf{9 . 1 0}$ & $\mathbf{0 . 7 3}$ & $\mathbf{0 . 8 6}$ & $\mathbf{0 . 4 4}$ & $\mathbf{0 . 9 7}$ & 1.09 & 0.8 \\
\hline
\end{tabular}

\subsection{Experimental procedure}

In all experiments the volume of the nanofluid present in the still basin was kept constant at $0.05 \mathrm{~m}^{3}$ which gives a depth of about $0.07 \mathrm{~m}$ in the still basin. This was attained by using a float present inside the still connected to the outer ordinary water feed line while the amount of the nanomaterial present in the still was kept constant during each experiment. The nanofluid present in the still must be discarded and replaced by a fresh one when its salinity reached 140,000 ppm as with such salinity the boiling point of the basin fluid reaches $102 \mathrm{C}^{\mathrm{o}}$ under atmospheric pressure [19]. Duration of such replacement is determined by the still productivity.

Water based nanofluids containing either $\mathrm{Fe}_{2} \mathrm{O}_{3}$ or RCBW had been prepared at different volume concentrations of $0.005,0.01,0.015$ and 0.02 vol \% by using the two -step method [20]. In this method, nanoparticles were added to water and an ultrasonic unit was used to intensively disperse them till obtaining a homogenous suspension. This suspension was directly fed to the still basin [21, 22].

Experiments were accomplished first with ordinary water and then with the various nanofluids during June and July 2021 at the open roof of the Faculty of Engineering, Tanta University, Tanta (Latitude: $30.8^{\circ}$, Longitude: $31^{\circ}$ ), Egypt. The experimental set up was positioned to face north - south orientation and the experimental data had been monitored hourly from 8 AM to 5 PM local time. These data include, ambient, inner surface of the glass cover, basin fluid temperatures and the accumulated condensate. No solar isolation measurements were made in this study and the data needed in this respect were obtained from Faculty of Engineering, Tanta University.

\section{RESULTS AND DISCUSSION}

Figs. (3-7) present three examples from the nineteen registered measurements for the experiments conducted in the present study. These include the hourly solar radiation (I, $\mathrm{W} / \mathrm{m}^{2}$ ), distillate output $\left(\mathrm{P}, \mathrm{ml} / \mathrm{m}^{2} . \mathrm{h}\right)$ and ambient $(\mathrm{Ta})$, basin fluid $(\mathrm{Tb})$ and glass cover inner surface (Tgi) temperatures $\left({ }^{\circ} \mathrm{C}\right)$. These figures show that the values of these variables increase as time goes on from the morning reaching their higher values during noon interval (11:00 AM to 3:00 PM) then begin decrease after 3:00 PM. The maximum recorded solar radiation was $990 \mathrm{~W} / \mathrm{m}^{2}$ and the corresponding ambient, basin fluid and glass cover inner surface temperatures were $38^{\circ} \mathrm{C}, 65^{\circ} \mathrm{C}$ and $50^{\circ} \mathrm{C}$, respectively at 12 June 2021 .

For all the experimental measurements, there are a clear direct relationship between the values of solar radiation and those for the other mentioned variables. The increase in the distillate outputs was also dependant upon type and concentration of the basin fluid.

For the first day of operation of the solar still containing a specified nanofluid the effect of nanofluid type and concentration upon its hourly distillate output $(\mathrm{P})$ is presented in Table 3 while Fig. 8 gives such effect on the percent increase in hourly distillate output relative to ordinary water (P). Presented figures reveal that an increase in the still yield was observed for both the tested nanomaterials while the gain achieved with $\mathrm{Fe}_{2} \mathrm{O}_{3}$ nanofluid exceeded those for RCBW nanofluid at all the concentrations used.

For both nanomaterials, the rise in concentration adds to the still yield which reached their maximum values; $11 \%$ and 9.5\% for $\mathrm{Fe} 2 \mathrm{O} 3$ and $\mathrm{RCBW}$ respectively at $0.01 \mathrm{vol} \%$ then a depletion in the still yield was recorded with additional increase in concentration.

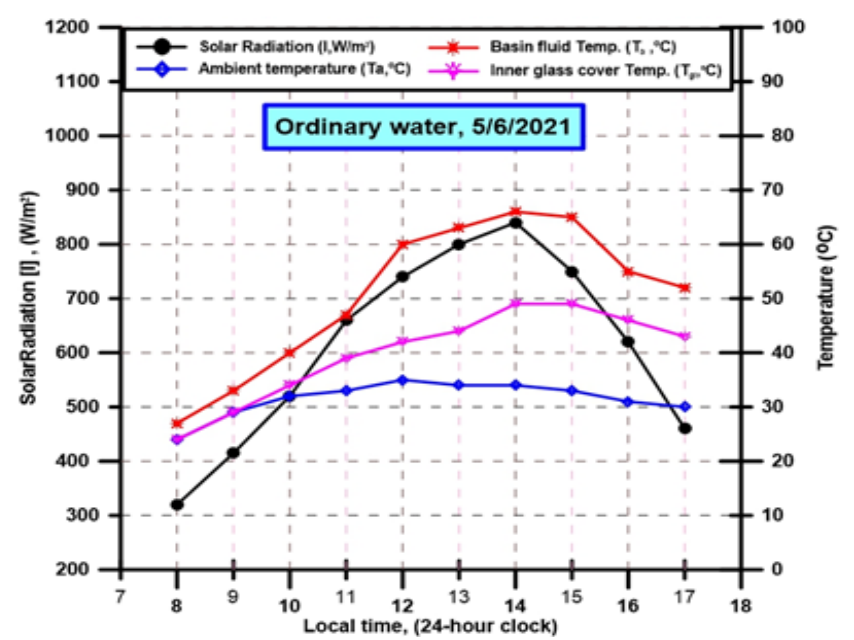

Fig. 3: Hourly variations of solar radiation, ambient, still basin fluid and glass cover inner surface temperatures for ordinary water, Date of experiment: 5/6/2021 


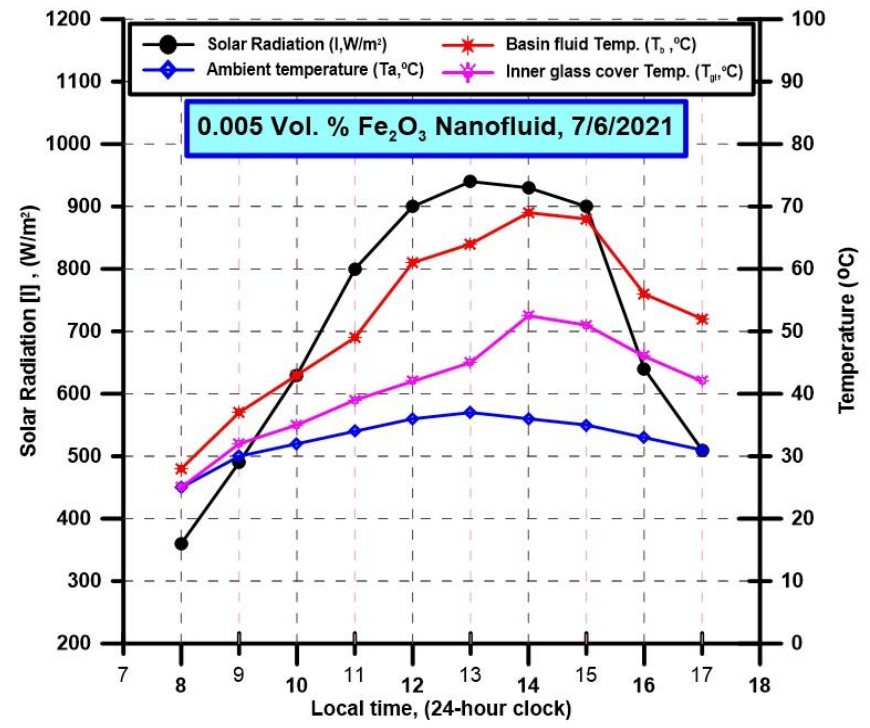

Fig. 4: Hourly variations of solar radiation, ambient, still basin fluid and glass cover inner surface temperatures for 0.005 vol $\% \mathrm{Fe}_{2} \mathrm{O}_{3}$ nanofluid, Date of experiment: $7 / 6 / 2021$

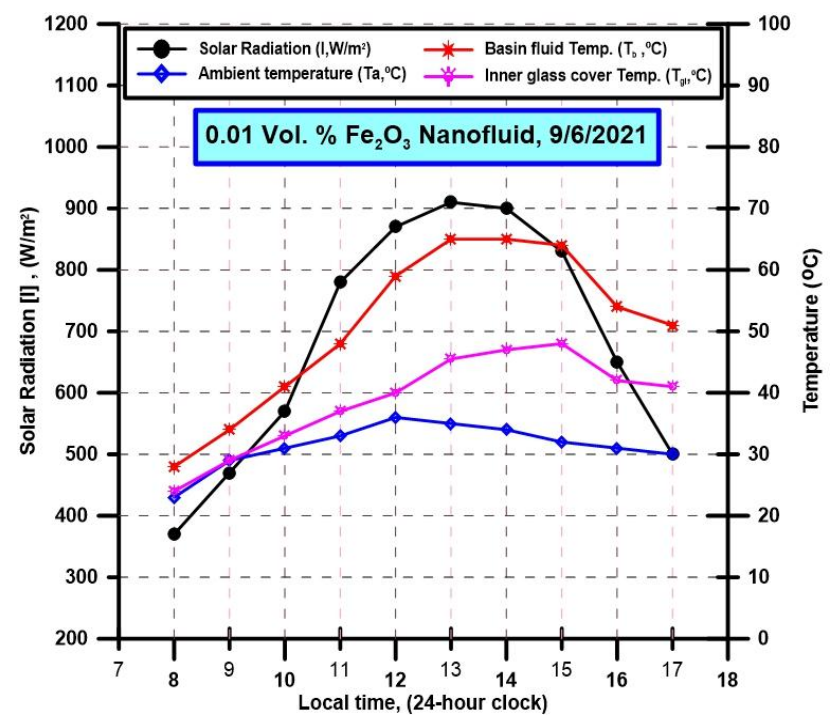

Fig. 5: Hourly variations of solar radiation, ambient, still basin fluid and glass cover inner surface temperatures for 0.01 vol $\% \mathrm{Fe}_{2} \mathrm{O}_{3}$ nanofluid, Date of experiment: $9 / 6 / 2021$

The noticed gain in solar still yield when using nanofluids in the still basin is due to the increase in the rate of vaporization of water present with the nanoparticles in the still basin. The increase in water vaporization is attributed to more heat energy gain by the nanofluid present in the still basin due to more solar radiation absorption capacity, improvement of the heat capacity and internal convective heat transfer coefficient in the still basin fluid which are related to the presence of nanofluids in it. Enhancement of solar radiation absorption using nanoparticles suspensions over that recorded for the base fluid have been reported in numerous studies where the base fluid is transparent. Such effect was remarkable in the visible and near - infrared wavelengths which are characteristics of solar radiation. At the same time, absorption coefficient of the nanoparticle suspension in the infrared region, which dominates thermal radiation emitted from the suspension remains the same as one of the base fluid.

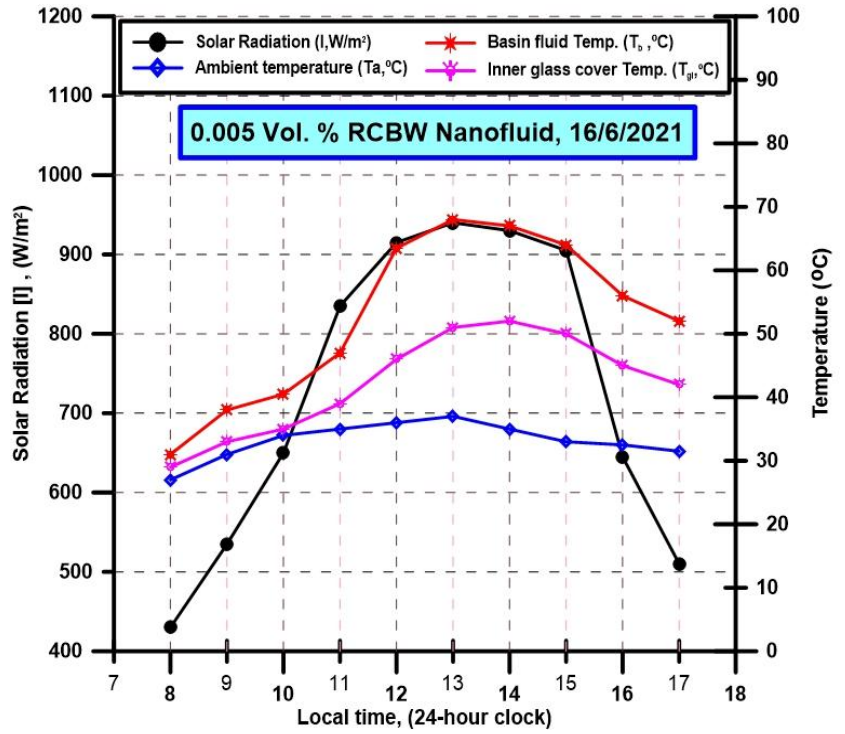

Fig. 6: Hourly variations of solar radiation, ambient, still basin fluid and glass cover inner surface temperatures for 0.005 vol \% RCBW nanofluid, Date of experiment: 16/6/2021

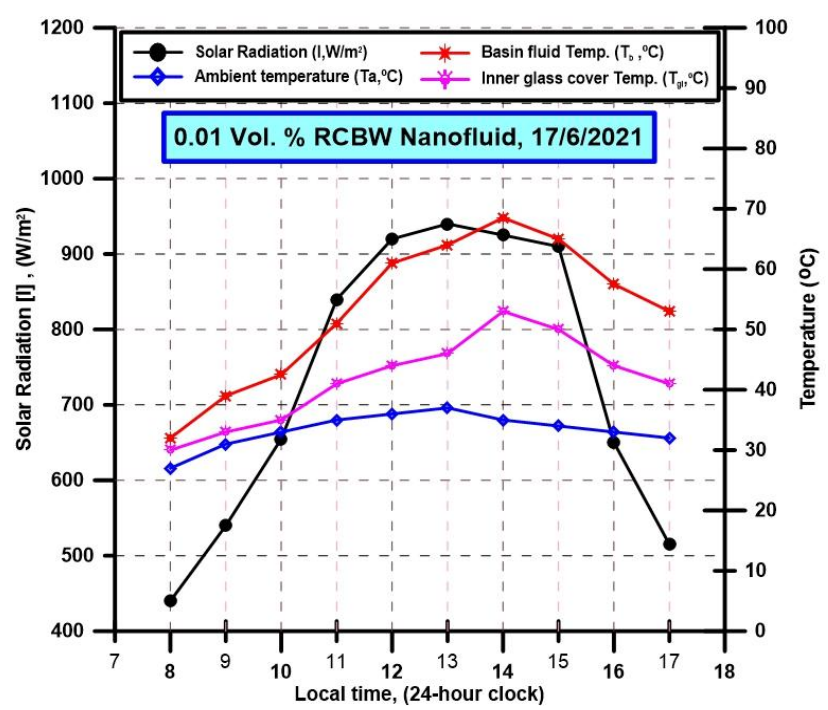

Fig. 7: Hourly variations of solar radiation, ambient, still basin fluid and glass cover inner surface temperatures for 0.01 vol \% RCBW nanofluid, Date of experiment: 17/6/2021

In this respect, nanoparticles can be considered as active photo-thermal sites able to absorb the specified solar radiation wavelengths very strongly and convert them efficiently into heat energy. Experimental results of many researchs in the literature demonstrated that the thermal conductivities of all nanofluids were higher than those of their base fluids.

Although metal oxides have lower thermal conductivities compared to their corresponding metals, they are still having higher thermal conductivities than that of water which is also the case with nonmetallic oxides. Hence, nanofluids composed of suspended metals or nonmetals oxides in water manifested enhanced thermal conductivities relative to water, but such effect is more pronounced with metallic oxides than nonmetallic oxides due to their higher thermal conductivites which is the case in the present study. The significant increase of the thermal conductivity has active effects in heat transfer characteristics in the solar still basin containing nanofluid such as micro layer evaporation and reformation of 
the thermal boundary layer. Also when vaporization from surface sublayers grows as the basin fluid temperature rises to its maximum value around the mid-day , the heat transfer coefficient in the basin fluid increases because of the contribution of the growing bubbles to the turbulence in the laminar subsurface layer, which also adds to the convective heat transfer in this layer.

In addition to that nanofluids exhibit thermal properties superior to those of their base fluids, nanoparticles represent active nucleation sites inside the nanofluid which aid heat transfer. This adds to the improvements in heat transfer characteristics inside the nanofluid present in the still basin causing more water vaporization and hence improves its productivity.

In general the operation of solar stills is intermittent as they work and act only during sunshine hours. Hence on using nanofluids in solar stills, along their operation period the nanofluid suspension loose their stability specially during offshine sun hours where the suspension is completely stationary. Loss of stability of nanoparticles lead to the formation of nanoclusters which in turn aggregate forming larger ones that aid gravity- driven sedimentation of such clusters. The end result is a continuous changes in both the number and distribution of the nanoparticles in the suspension and hence its concentration and homogeneity. These effects negatively affect both optical and heat transfer characteristics of the nanofluid suspension present in the still. It causes continuous decrease in the number of active nucleation and photo-thermal sites inside the nanofluid suspension. These phenomenon negatively affect the rate of vaporization and condensation of water from the still basin and hence its distillate output.

The negative effects of intermittent operation of the solar still containing nanofluids are more pronounced at higher nanoparticles concentrations as the nanoparticles can agglomerate more easily in more concentrated nanofluids because they are closer to one another. The grow of nanoclusters into larger clusters occurs more actively and rapidly as the concentration increases. This adds to the negative effects on the thermal properties of the nanofluid in addition to cause a decrease in active nucleation sites and causes extra thermal resistance to the boiling surface in the fluid. On the other hand, the number of active photo- thermal sites inside the nanofluid are also reduced.

For $\mathrm{Fe}_{2} \mathrm{O}_{3}$ nanofluids, three successive days of intermittent operation were sufficient to reach $65.7 \%$ and $79.4 \%$ reduction in the percent increase in hourly distillate output for $0.01 \quad \mathrm{vol} \%$ and $0.02 \quad \mathrm{vol} \% \quad \mathrm{Fe}_{2} \mathrm{O}_{3}$ concentrations respectively while for RCBW nanofluids only $40.3 \%$ and $52.3 \%$ reduction in the percent increase in hourly distillate output for $0.01 \mathrm{vol} \%$ and $0.02 \mathrm{vol} \%$ RCBW concentrations respectively were recorded after three consecutive days. This is due to the differences in the thermal conductivity and zeta potential between $\mathrm{Fe}_{2} \mathrm{O}_{3}$ and RCBW nanoparticles which determine the tendency of aggregation, clustering and hence sedimentation of the nanoparticles present in the nanofluid suspension. So, it was sufficient to operate the solar still for only three consuctive days when using $\mathrm{Fe}_{2} \mathrm{O}_{3}$ nanofluid to loose over $70 \%$ of the still productivity, while more time is needed for RCBW nanofluid to reach similar effect. Hence RCBW nanofluids were tested for four successive days.

\section{CONCLUSION}

Based on the results of the present study, the following conclusions are drawn:

- As time goes on from morning, all temperatures and the still yield increase and have peak values around the nooninterval then begin to decrease after 3:00 PM with respect to the variation of the solar radiation.

- The still yield is dependent on the type and concentration of the used nanofluid while the gain achieved with $\mathrm{Fe}_{2} \mathrm{O}_{3}$ nanofluid exceeded that for RCBW nanofluid at all the concentration used.

- For both nanomaterials the rise in concentration adds to the still yield reaching maximum values; $11 \%$ and $9.5 \%$ for $\mathrm{Fe}_{2} \mathrm{O}_{3}$ nanofluid and RCBW nanofluid respectively at $0.01 \mathrm{vol} \%$ then a depletion in the still yield is recorded with additional increase in concentration.

- The operation of solar still is intermittent which leads to a continuous decrease in its yield over the operating period due to the loss of nanofluid stability with time. This bad impact is more pronounced at higher nanoparticles concentrations.

- Over $70 \%$ depletion in the still yield relative to that obtained in the first day of operation was recorded in the third day of operation for $\mathrm{Fe}_{2} \mathrm{O}_{3}$ nanofluids while four consecutive days of operation were needed for RCBW nanofluids to cause similar effect. This is attributed to the difference in thermal conductivity and zeta potential difference between $\mathrm{Fe}_{2} \mathrm{O}_{3}$ and RCBW nanoparticles.

\section{List of symbols and abbrivations}

\begin{tabular}{ll}
$\mathrm{RCBW}$ & Red Clay Brick Waste \\
\hline $\mathrm{XRF}$ & X-ray fluorescence \\
\hline $\mathrm{Fe}_{2} \mathrm{O}_{3}$ & Ferric Oxide \\
\hline $\mathrm{SiO}_{2}$ & Silicon dioxide \\
\hline $\mathrm{Al}_{2} \mathrm{O}_{3}$ & Aluminum oxide \\
\hline $\mathbf{I}$ & Solar radiation \\
\hline $\mathbf{P}$ & Distillate output \\
\hline $\mathbf{P} \square$ & Ordinary water \\
\hline $\mathbf{T a}$ & Ambient Temperature \\
\hline $\mathbf{T b}$ & Basin fluid Temperature \\
\hline $\mathbf{T g i}$ & Glass cover inner surface Temperature
\end{tabular}

\section{REFERENCES}

[1] M. I. Baig, P. G. Ingole, J.-d. Jeon, S. U. Hong, W. K. Choi, B. Jang, and H. K. Lee, "Water vapor selective thin film nanocomposite membranes prepared by functionalized Silicon nanoparticles," Desalination, vol. 451, pp. 59-71, 2019/02/01/, 2019.

[2] S. Chede, N. M. Anaya, V. Oyanedel-Craver, S. Gorgannejad, T. A. L. Harris, J. Al-Mallahi, M. Abu-Dalo, H. A. Qdais, and I. C. Escobar, "Desalination using low biofouling nanocomposite 
membranes: From batch-scale to continuous-scale membrane fabrication," Desalination, vol. 451, pp. 81-91, 2019/02/01/, 2019.

[3] G.-R. Xu, J.-M. Xu, H.-C. Su, X.-Y. Liu, L. Lu, H.-L. Zhao, H.-J Feng, and R. Das, "Two-dimensional (2D) nanoporous membranes with sub-nanopores in reverse osmosis desalination: Latest developments and future directions," Desalination, vol. 451, pp. 1834, 2019/02/01/, 2019.

[4] Y. H. Teow, and A. W. Mohammad, "New generation nanomaterials for water desalination: A review," Desalination, vol. 451, pp. 2-17, 2019/02/01/, 2019

[5] W. Chen, C. Zou, X. Li, and H. Liang, "Application of recoverable carbon nanotube nanofluids in solar desalination system: An experimental investigation," Desalination, vol. 451, pp. 92-101, 2019/02/01/, 2019.

[6] R. Das, and M. Khayet, "Nanotechnology Based Platforms for Efficient Water Desalination," Desalination, vol. 451, pp. 1, 2019/02/01/, 2019

[7] S. M. Parsa, A. Rahbar, M. H. Koleini, Y. Davoud Javadi, M. Afrand, S. Rostami, and M. Amidpour, "First approach on nanofluid-based solar still in high altitude for water desalination and solar water disinfection (SODIS)," Desalination, vol. 491, pp. 114592, 2020/10/01/, 2020

[8] S. M. Parsa, A. Rahbar, M. H. Koleini, S. Aberoumand, M. Afrand, and M. Amidpour, "A renewable energy-driven thermoelectricutilized solar still with external condenser loaded by silver/nanofluid for simultaneously water disinfection and desalination," Desalination, vol. 480, pp. 114354, 2020/04/15/, 2020.

[9] S. Arora, H. P. Singh, L. Sahota, M. K. Arora, R. Arya, S. Singh, A Jain, and A. Singh, "Performance and cost analysis of photovoltaic thermal (PVT)-compound parabolic concentrator (CPC) collector integrated solar still using CNT-water based nanofluids," Desalination, vol. 495, pp. 114595, 2020/12/01/, 2020.

[10] H. Panchal, K. K. Sadasivuni, A. A. A. Ahmed, S. S. Hishan, M. H. Doranehgard, F. A. Essa, S. Shanmugan, and M. Khalid, "Graphite powder mixed with black paint on the absorber plate of the solar still to enhance yield: An experimental investigation," Desalination, vol 520, pp. 115349, 2021/12/15/, 2021.

[11]M. Muraleedharan, H. Singh, M. Udayakumar, and S. Suresh, "Modified active solar distillation system employing directly absorbing Therminol 55-A12O3 nano heat transfer fluid and Fresnel lens concentrator," Desalination, vol. 457, pp. 32-38, 2019/05/01/, 2019.

[12] L. Sahota, and G. N. Tiwari, "Effect of nanofluids on the performance of passive double slope solar still: A comparative study using characteristic curve," Desalination, vol. 388, pp. 9-21, 2016/06/15/, 2016.

[13] T. Elango, A. Kannan, and K. Kalidasa Murugavel, "Performance study on single basin single slope solar still with different water nanofluids," Desalination, vol. 360, pp. 45-51, 2015/03/16/, 2015.

[14]H. Rostamzadeh, and S. Rostami, "Performance enhancement of waste heat extraction from generator of a wind turbine for freshwater production via employing various nanofluids," Desalination, vol. 478 , pp. $114244,2020 / 03 / 15 /, 2020$.

[15]A. K. Thakur, R. Sathyamurthy, R. Velraj, R. Saidur, and J.-Y Hwang, "Augmented performance of solar desalination unit by utilization of nano-silicon coated glass cover for promoting drop-wise condensation," Desalination, vol. 515, pp. 115191, 2021/11/01/, 2021

[16]F. Alnaimat, M. Ziauddin, and B. Mathew, "A review of recent advances in humidification and dehumidification desalination technologies using solar energy," Desalination, vol. 499, pp. 114860 , 2021/02/01/, 2021

[17] L. Chen, H. Wang, S. Kuravi, K. Kota, Y. H. Park, and P. Xu, "Lowcost and reusable carbon black based solar evaporator for effective water desalination," Desalination, vol. 483, pp. 114412, 2020/06/01/, 2020.

[18] A. M. Gandhi, S. Shanmugan, S. Gorjian, C. I. Pruncu, S. Sivakumar, A. H. Elsheikh, F. A. Essa, Z. M. Omara, and H. Panchal, "Performance enhancement of stepped basin solar still based on OSELM with traversal tree for higher energy adaptive control," Desalination, vol. 502, pp. 114926, 2021/04/15/, 2021.

[19] N. S. Fuzil, N. H. Othman, N. H. Alias, F. Marpani, M. H. D Othman, A. F. Ismail, W. J. Lau, K. Li, T. D. Kusworo, I. Ichinose, and M. M. A. Shirazi, "A review on photothermal material and its usage in the development of photothermal membrane for sustainable clean water production," Desalination, vol. 517, pp. 115259 , 2021/12/01/, 2021
[20] W.-L. Cheng, Y.-K. Huo, and Y.-L. Nian, "Performance of solar still using shape-stabilized PCM: Experimental and theoretical investigation," Desalination, vol. 455, pp. 89-99, 2019/04/01/, 2019.

[21] R. A. Kumar, G. Esakkimuthu, and K. K. Murugavel, "Performance enhancement of a single basin single slope solar still using agitation effect and external condenser," Desalination, vol. 399, pp. 198-202, 2016/12/01/, 2016.

[22] S. M. Parsa, D. Javadi Y, A. Rahbar, M. Majidniya, M. Salimi, Y. Amidpour, and M. Amidpour, "Experimental investigation at a summit above 13,000ft on active solar still water purification powered by photovoltaic: A comparative study," Desalination, vol. 476, pp. $114146,2020 / 02 / 15 /, 2020$ 